\title{
Technical Basis for a Minimum Hydroxide Concentration in Tanks Containing Dilute Waste (U)
}

by

P. E. Zapp

Westinghouse Savannah River Company

Savannah River Site

Aiken, South Carolina 29808

DOE Contract No. DE-AC09-89SR 18035

This paper was prepared in connection with work done under the above contract number with the U.S.

Department of Energy. By acceptance of this paper, the publisher and/or recipient acknowledges the U.S. Government's right to retain a nonexclusive, royalty-free license in and to any copyright covering this paper, along with the right to reproduce and to authorize others to reproduce all or part of the copyrighted paper.

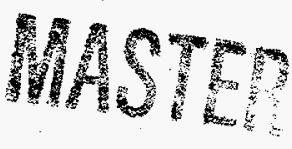

DISTRIBUTTON OF THS DOCUMENT IS UNLQMTED 


\section{DISCLATMER}

This report was prepared as an account of work sponsored by an agency of the United States Government: Neither the United States Government nor any agency thereof, nor any of their employees, makes any warranty, express or implied, or assumes any legal liability or responsibility for the accuracy, completeness, or usefulness of any information, apparatus, product or piocess disclosed, or represents that its use would not infringe privately owried rights. Reference herein to any specific commercial product, process, or service by trade name, trademark, manufacturer, or otherwise does not necessarily consitute or imply its endorsement, recommendation, or favoring by the United States Government or any agency thereof. The views and opinions of authors expressed herein do not necessarily state or reflect those of the United States Government or any agency thereof.

This report has been reproduced directly from the best available copy.

Available to DOE and DOE contractors from the Office of Scientific and Technical Information, P.O. Box 62, Oak Ridge, TN 37831; prices available from (615) 57.6-8401.

Available to the public from the National Technical Information Service, U.S. Department of Commerce, 5285 Poit Royal Road, Springfield, VA 22161. 


\section{DISCLAIMER}

Portions of this document may be illegible in electronic image products. Images are produced from the best available original document. 


\title{
$A S E T$
}

APPLIED SCIENCE \& ENGINEERING TECHNOLOGY

WSRC-TR-95-0213

Revision 0

\author{
APPLIED SCIENCE \& ENGINEERING TECHNOLOGY
}

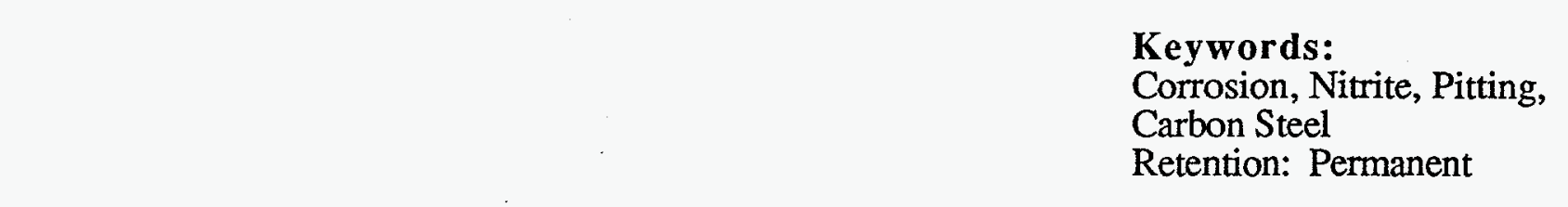

TECHNICAL BASIS FOR A MINIMUM HYDROXIDE

CONCENTRATION IN TANKS CONTAINING DILUTE WASTE (U)

Philip E. Zapp

Issued: May 1995
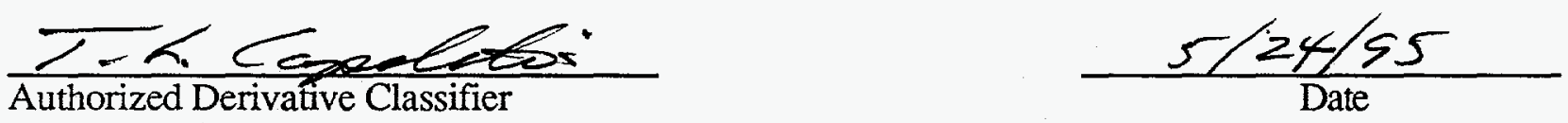

SRTC SAVANNAH RIVER TECHNOLOGY CENTER, AIKEN, SC 29808

Westinghouse Savannah River Company

Prepared For The U.S. Department Of Energy Under Contract DE-AC09-89SR18035

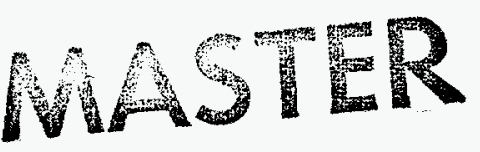




\section{DOCUMENT: WSRC-TR-95-0213 Revision 0}

\section{TITLE: TECHNICAL BASIS FOR A MINIMUM HYDROXIDE CONCENTRATION IN TANKS CONTAINING DILUTE WASTE(U)}

\section{APPROVALS}

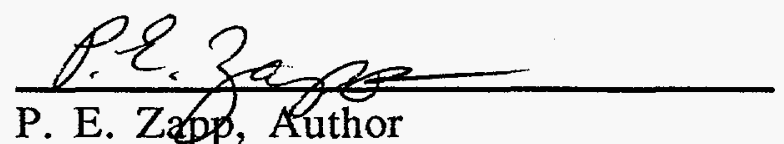

Date: $5-23-55$

P. E. Zapp, Author

Materials Applications \& Corrosion Technology Group

Materials Technology Section

Acl. Muekalania

Date: $5-24-95$

J. I. Mickalonis, Technical Reviewer

Materials Applications \& Corrosion Technology Group

Materials Technology Section

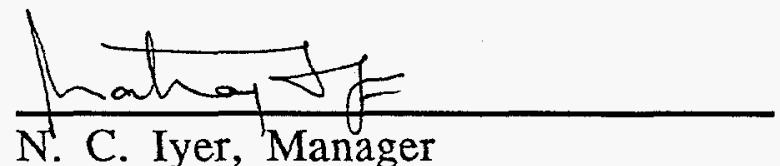

Date: $-5-24-95$

Materials Applications \& Corrosion Technology Group

Materials Technology Section

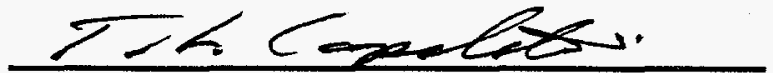

Date: $-5 / 24 / 55$

T. L. Capeletti, Manager

Materials Technology Section 


\section{TECHNICAL BASIS FOR A MINIMUIM HYDROXIDE CONCENTRATION IN TANKS CONTAINING DILUTE WASTE (U)}

\section{SUMMARY}

Laboratory tests were performed to address the protection of waste tank steel from corrosion in situations of elevated temperatures up to $75^{\circ} \mathrm{C}$ (hot spots) in the sludge layer of Extended Sludge Processing (ESP) tanks. Coupon immersion tests were conducted at $75{ }^{\circ} \mathrm{C}$ in two ESP simulants at four hydroxide (or $\mathrm{pH}$ ) levels. The nitrite concentrations of the simulants were calculated from the ESP technical standards based on a temperature of $40{ }^{\circ} \mathrm{C}$. The results showed that a hydroxide concentration of at least $0.01 \mathrm{M}$ prevented significant corrosion of the steel at the elevated temperature. This conclusion provides the technical basis for the revised minimum hydroxide concentration of $0.01 \mathrm{M}$ in the draft WSRC 241-82H Control Room Process Requirements.

\section{INTRODUCTION}

Pitting corrosion in dilute high-level radioactive waste solutions can be prevented by maintaining sufficient concentrations of hydroxide and nitrite. The required nitrite concentration to prevent pitting in Extended Sludge Processing (ESP) tanks is given in the ESP technical standards, in which the nitrite level is a function of the nitrate concentration and the temperature of the waste, for temperatures between $20^{\circ} \mathrm{C}$ and 60 ${ }^{\circ} \mathrm{C}$.[1] The dependence on temperature is strong, with a temperature increase from 40 ${ }^{\circ} \mathrm{C}$ to $60^{\circ} \mathrm{C}$ yielding a factor of 6.6 increase in the required nitrite concentration. Nitrite is added to waste tanks as a concentrated sodium nitrite solution. In addition to the increased expense of supplying the inhibitor, higher nitrite also means higher sodium levels, which require further washing to meet alkali limits in the feed to the Defense Waste Processing Facility. High temperatures are, therefore, undesirable because they demand high nitrite concentrations.

The protective nitrite limit is based on the supernate temperature because carbon steel is first vulnerable to pitting at the supernate-air interface. Atmospheric carbon dioxide quickly dissolves into the liquid film at the interface and depletes hydroxide by reacting with it to form bicarbonate and carbonate.[2] Carbon steel becomes susceptible to pitting at $\mathrm{pHs}$ below the 10-to-12 range, depending on aggressive ion content. The steady-state $\mathrm{pH}$ in the film falls to between 9.5 and 10.4, depending on the bulk waste composition and partial pressure of carbon dioxide in the atmosphere. This susceptibility is offset by added nitrite, which acts with the remaining hydroxide to prevent the breakdown of the passive oxide layer on the steel. Hydroxide depletion is fast in the liquid film at the interface, with steady state being achieved in a few hours. However, the time to reach steady state throughout the bulk waste volume is of the order of years. Therefore, the steel that is initially susceptible to pitting lies under the interfacial film.

Operating experience has shown that a dilute high-level waste tank may have nonuniform temperatures. There have been instances when the temperature in the sludge layer of ESP tanks exceeds the supernate temperature. The higher temperature can 
arise from the operation of slurry pumps and the distribution of heat-generating radionuclides in the sludge layer. With the nitrite inhibitor level set by the lower supernate temperature, the higher temperature readings raised the question of the susceptibility of nearby steel to corrosive attack. Specifically in early June, 1994, a hot spot or region of high temperature was observed near the $\mathrm{H}$ slurry pump in tank $42 \mathrm{H}$. A thermocouple attached to the outside of the tank bottom near this location registered $57^{\circ} \mathrm{C}$; at the same time the supernate temperatures in tank $42 \mathrm{H}$ were of the order of 35 ${ }^{\circ} \mathrm{C}$.[3] After the slurry pumps were shut down, the temperature at the hot spot decreased to $<50{ }^{\circ} \mathrm{C}$. Throughout this time, the nitrite concentration exceeded the minimum required by the technical standards, which is based on the supernate temperature. The nitrite level was sufficient to prevent pitting at supernate temperatures up to $49^{\circ} \mathrm{C}$ for the existing tank nitrate concentration.

The Waste Tank Corrosion Working Group determined that the hot spot did not render the tank bottom vulnerable to corrosion because the chemical conditions in the sludge are less aggressive than those at the liquid-vapor interface. The hydroxide concentration in tank $42 \mathrm{H}$ was $0.02 \mathrm{M}$ ( $\mathrm{pH}$ of $\sim 12.3$ ) at the time of the hot spot occurrence. The bulk hydroxide concentration is much greater than the hydroxide level in the aqueous film at the liquid-vapor interface, which is the level that drives the nitrite requirement. The concentration of nitrate is likely to be lower in the sludge, because more nitrate is destroyed by radiolysis in the radionuclide-rich sludge than in the supernate.[4] Thus, the higher hydroxide and lower nitrate in the sludge hot spot should offset the effects of higher temperature and render the steel immune to corrosion.

The present work was undertaken to confirm experimentally the immunity of carbon steel to corrosion under conditions similar to those of the tank $42 \mathrm{H}$ hot spot: a temperature well above the supernate temperature and a free hydroxide concentration of at least $0.01 \mathrm{M}$. Specifically, experimental verification was sought for the protection of carbon steel at $75{ }^{\circ} \mathrm{C}$ with ESP simulants containing $0.01 \mathrm{M}$ hydroxide and nitrite at a concentration appropriate for $40^{\circ} \mathrm{C}$. The $40^{\circ} \mathrm{C}$ temperature was chosen as a typical supernate temperature in ESP tanks.

\section{EXPERIMENTAL PROCEDURE}

Long-term coupon immersion tests were conducted at $75{ }^{\circ} \mathrm{C}$ in non-radioactive simulants of two intermediate dilutions or washes of an average ESP slurry. The simulants were based on the calculated average washed sludge composition reported in the Defense Waste Processing Facility Basic Data Report.[5] The particular washes were chosen as representatives of dilute ESP solutions in which pitting is prevented with nitrite additions. They will be referred to as "5th wash" and "10th wash". The 5th wash composition represented approximately $19 \%$ of the unwashed sludge composition, and the 10th wash approximately $3.8 \%$. The calculated nitrate concentration in unwashed sludge solution is $1.44 \mathrm{M}$. Thus, the nitrate concentrations were $0.280 \mathrm{M}$ for the 5 th wash and $0.0546 \mathrm{M}$ for the 10 th wash. The composition of the 5 th wash simulant is shown in Table $1 ; 10$ th wash concentrations were a factor of 5.12 lower. Four oneliter volumes of each composition were prepared from reagent grade chemicals and distilled water. The nitrite concentration in each simulant was that specified by the technical standards to prevent pitting at $40^{\circ} \mathrm{C}$. Sodium hydroxide and sodium carbonate were added to each volume to produce a series of buffered $\mathrm{pHs}$ : for the 5 th wash, 10, 10.4, 12.0, and 12.6; and for the 10th wash, 10.0,11.0,11.9, and 12.5.[6] The 
sodium hydroxide additions accounted for the consumption of hydroxide in the precipitation of transition metal hydroxides (e.g., ferric hydroxide) and in the conversion of the $\mathrm{Al}^{+3}$ ion to $\mathrm{Al}(\mathrm{OH})_{4}{ }^{-}$.

The coupons used in this study were fabricated from ASTM A537 class 1 carbon steel and supplied by Metal Samples, Inc., Munford, Ala. Their size was 0.75 in. by 3 in. by 0.12 in., and they were used in the as-received condition with 600 grit surface finish. The coupons were cleaned in acetone, rinsed in distilled water, dried, and weighed. Four coupons were suspended in one-liter polyethylene bottles with Teflon ${ }^{\mathrm{TM}}$-coated wire. The bottles were filled with one liter of test solution, sealed, and placed in a convection oven set at $75^{\circ} \mathrm{C}$. The coupons were maintained at temperature for 142 days.

Upon removal from the test solutions, the coupons were cleaned in either inhibited hydrochloric acid or a sodium hydroxide solution - zinc mixture, weighed, and examined with optical microscopy. Uniform corrosion rates were calculated from the weight loss, and depths of corrosive attack were measured with a digital-micrometerequipped microscope.

\section{RESULTS AND DISCUSSION}

In general the coupons had patches of light uniform corrosion of somewhat irregular depth. Distinct pitting separate from the patches of uniform corrosion was not observed. In the course of the test, sufficient evaporation occurred to drop the liquid level below the tops of some coupons, thus exposing the steel to the more aggressive conditions of differential oxygenation at the water line. Consistent with these conditions, the light corrosion patches were located mainly on the upper half of the coupons, with the deepest points of attack coinciding with the water line.

Table 2 shows the average corrosion rate in mils per year calculated from the weight losses of the four coupons in each test. The table also includes the make-up, or initial $\mathrm{pH}$ and the post-test $\mathrm{pH}$ of each test solution. As expected, the corrosion rates were low. In 5th wash simulants the corrosion rate varied from 1.1 mils/yr for a make-up $\mathrm{pH}$ of 10.0 to $0.14 \mathrm{mils} / \mathrm{yr}$ for a make-up $\mathrm{pH}$ of 12.6. Among the 10 th wash simulants the corrosion rates were 1.3 mils/yr for a $\mathrm{pH}$ of 10.0 and 0.32 for a $\mathrm{pH}$ of 12.5 . Post-test measurements showed that the $\mathrm{pH}$ of the solutions tended to decrease especially in instances of a make-up pH of about 12 or higher. As can be seen in Table 2, the post-test $\mathrm{pH}$ was about 10.5 for the 5 th wash solutions and about 10.0 for the 10 th wash solutions. These pHs are low enough to induce corrosion in the absence of sufficient inhibitor. The test conditions were, therefore, more aggressive than they would have been if the $\mathrm{pH}$ had been maintained at a constant value.

The data indicated that carbon steel exposed to $75^{\circ} \mathrm{C}$ ESP solutions containing hydroxide at a pH of 12 and nitrite at a value appropriate for only $40^{\circ} \mathrm{C}$ was not subject to significant corrosion. The highest measured corrosion rate was only $1.3 \mathrm{mils} / \mathrm{yr}$ at a make-up pH of 10.0. This rate falls in the range categorized as "ideal" in the Corrosion Data Survey, which applies that label to rates less than 2 mils/yr.[7] The measured rate is less than $4 \mathrm{mils} / \mathrm{yr}$, which places it in the range defined as "resistant" in the DECHEMA Corrosion Handbook. Actual ESP tank conditions should result in a corrosion rate less than $1.3 \mathrm{mils} / \mathrm{yr}$, because of the lower temperatures and limited duration of hot spots. In Tank $42 \mathrm{H}$, for example, a hot spot was observed in 1988 with a maximum temperature in the 50 to $60^{\circ} \mathrm{C}$ range.[9] The $75^{\circ} \mathrm{C}$ test temperature 
WSRC-TR-95-0213

Page 4 of 6

represents a high value for a hot spot. Under the typical hot spot temperatures of $<60$ ${ }^{\circ} \mathrm{C}$, the actual corrosion rate is expected to be $<1 \mathrm{mil} / \mathrm{yr}$ because chemical reactions decrease in general by a factor of 2 for each $10^{\circ} \mathrm{C}$ drop in temperature.[10] The limited duration of hot spots means that the waste tanks will be exposed to such rates only infrequently. The potential metal loss as a result of hot spots is, therefore, insignificant when the hydroxide concentration is maintained at a minimum of $0.01 \mathrm{M}$ and the nitrite concentration is maintained at a value calculated for $40^{\circ} \mathrm{C}$.

\section{CONCLUSIONS}

Laboratory tests were performed to investigate the protection of waste tank steel from corrosion in situations of elevated temperature up to $75^{\circ} \mathrm{C}$ (hot spots) in the sludge layer of Extended Sludge Processing (ESP) tanks. Coupon immersion tests were conducted at $75^{\circ} \mathrm{C}$ in two ESP simulants at four hydroxide (or $\mathrm{pH}$ ) levels and nitrite concentrations based on $40^{\circ} \mathrm{C}$. The results show that a hydroxide concentration of at least $0.01 \mathrm{M}$ prevents significant corrosion of the steel at the elevated temperature.

This conclusion provides the technical basis for the revised minimum hydroxide concentration of $0.01 \mathrm{M}$ in the draft WSRC 241-82H Control Room Process Requirements for the ESP tanks. This limit applies under conditions of a tank bottom or sludge temperature exceeding the supernate temperature when the nitrate concentration is < 1.0 M. The nitrite inhibitor level continues to be based on the ESP supernate temperature and the nitrate, chloride, or sulfate concentration. 


\section{REFERENCES}

1. Technical Standard for the Waste Tank Farms, DPSTS-241-5.03, December 19, 1990.

2. D. T. Hobbs, "Hydroxide Depletion in Washed Precipitate Slurry," DPST-87-663, December 9, 1985.

3. B. J. Wiersma, "Corrosion Working Group (COWOG) Meeting Minutes June 7,1994," SRT-MTS-94-2016, July 5, 1994.

4. D. T. Hobbs, "Supernatant Liquid Sampling in Waste Tanks," WSRC-RP-92-1179, Sept. 23, 1992.

5. Basic Data Report Defense Waste Processing Facility Sludge Plant, DPST-80-1033, Volume 2, Revision 90, October 30, 1984.

6. D. T. Hobbs, private communication, Sept. 13, 1994.

7. Corrosion Data Survey Metals Section, 6th Ed., National Association of Corrosion Engineers, Houston, 1985.

8. DECHEMA Corrosion Handbook, Vol. 3, VCH Publishing, New York, 1988.

9. D. T. Hobbs, "Summary of the June 27 Corrosion Working Group Meeting," July 5, 1989 and "Summary of the October 10 Corrosion Working Group Meeting," October 17, 1989.

10. Corrosion Basics An Introduction, National Association of Corrosion Engineers, Houston, 1984, p. 348. 
WSRC-TR-95-0213

Page 6 of 6

Table 1

Composition of 5th Wash ESP Simulant

Compound

Sodium Nitrate

Sodium Oxalate

Sodium Sulfate

Ferric Nitrate

Aluminum Nitrate

Cupric Nitrate

Mercuric Nitrate

Nickel Nitrate

Chromic Chloride

Sodium Chloride

Sodium Fluoride

Sodium meta-Silicate

Sodium Phosphate

Sodium Molybdate

Sodium Chromate

Sodium Nitrite

\section{Concentration, $\mathbf{M}$}

$1.24 \mathrm{E}-01$

$4.07 \mathrm{E}-04$

$1.86 \mathrm{E}-02$

$1.25 \mathrm{E}-02$

$3.41 \mathrm{E}-02$

$2.40 \mathrm{E}-03$

$3.78 \mathrm{E}-04$

$5.06 \mathrm{E}-03$

$2.77 \mathrm{E}-04$

$3.40 \mathrm{E}-03$

$2.12 \mathrm{E}-03$

4.03E-04

$1.14 \mathrm{E}-03$

$5.29 \mathrm{E}-05$

$4.07 \mathrm{E}-04$

$3.09 \mathrm{E}-01$

Table 2

pH Values and Average Corrosion Rates

Solution Make-Up pH Final pH Corrosion Rate, mils/yr

$\begin{array}{cccc}5 \text { th Wash } & 10.0 & 10.43 & 1.1 \\ & 10.4 & 10.43 & 0.15 \\ & 12.0 & 10.65 & 0.92 \\ & 12.6 & 10.49 & 0.14 \\ \text { 10th Wash } & 10.0 & 9.97 & \\ & 11.0 & 9.64 & 0.93 \\ & 11.9 & 9.99 & 1.2 \\ & 12.5 & 10.05 & 0.32\end{array}$


WSRC-TR-95-0213

Revision 0

\section{DISTRIBUTION:}

T. J. Lex, 719-4A

T. M. Monahon, 703-H

V. G. Dickert, 703-H

J. E. Marra, 703-H

H. A. Abodishish, 703-H

W. C. Clark, Jr., 241-119H

E. D. Lee, $241-152 \mathrm{H}$

L. S. Livingston, 703-H

W. B. Van Pelt, 241-152H

T. C. Hsu, 703-H

G. K. Georgeton, 703-H

M. R. Williams, 742-5G

L. M. Papouchado, 773-A

W. L. Tamosaitis, 773-A

S. D. Fink, 773-A

D. T. Hobbs, 773-A

J. D. Cohen, 730-A

T. L. Capeletti, 773-41A

N. C. Iyer, 773-A

P. E. Zapp, 773-A

B. J. Wiersma, 773-A

J. I. Mickalonis, 773-A

C. F. Jenkins, 730-A

Technical Information Management, 703-43A (4)

MTS Records, c/o V. W. Anderson, 773-41A 